\title{
Verification of the chemical subsystem of the regional climate model RegCM-CHEM4
}

\author{
Nikolay V. Volkov ${ }^{1}$, Anatoly A. Lagutin ${ }^{1,2}$ and Egor Yu. Mordvin ${ }^{1}$ \\ ${ }^{1}$ Altai State University, Barnaul, Russia \\ ${ }^{2}$ Federal Research Center for Information and Computational Technologies, Novosibirsk, Russia
}

\begin{abstract}
New simulation results, obtained from the chemical version of the regional climate model RegCMCHEM4, are presented for Siberian region. The verification of the chemical subsystem of the model with non-hydrostatic dynamical core is carried out using the atmospheric chemical transfer scheme CBMZ (Carbon Bond Mechanism-Z). To define chemical emissions the global RCP (Representative Concentration Pathways) emission dataset prepared by the International Institute for Applied Systems Analysis (IIASA), is used. For gas phase species, we have prepared the 6 hourly chemical boundary conditions from our modified version of the Model for Ozone and Related chemical Tracers, version 4 (MOZART-4). Quantitative estimates of methane emission in the atmosphere of the Siberian region have been obtained.
\end{abstract}

Keywords

Regional climate, Siberian region, atmospheric chemistry, methane, emission.

\section{Introduction}

Research over the past 20 years has shown that inverse atmospheric modeling combined with ground-based observations leads to more precise (versus direct measurements of the global terrestrial network) estimates of the spatial distribution of sources of the greenhouse gases (GHGs) [1]. At the same time, it was found that the scale of retrieval (e.g., a country, a single region, or an entire continent) highly depends on the quantity and distribution of measurement stations as well as their precision.

Despite the vast expansion of the global network of ground-based measurement stations, significant territories of South America, central Africa, zones of wetland complexes of Western Siberia, etc., which are sources of the GHGs, were not monitored.

Significant progress in the monitoring observations of the GHGs in the atmosphere of the Siberian region was achieved in 2004 by the commissioning of the Russian-Japanese network of ground stations [2]. Data from JR-STATION as well as the results of aircraft observations made by V.E. Zuev Institute of Atmospheric Optics SB RAS [3] are the only sources of information on the content of the GHGs in the atmosphere of Western Siberia.

SDM-2021: All-Russian conference, August 24-27, 2021, Novosibirsk, Russia

Ðvolkov@theory.asu.ru (N.V. Volkov); lagutin@theory.asu.ru (A. A. Lagutin); zion0210@gmail.com

(E. Yu. Mordvin)

(D) 0000-0002-3172-0655 (N. V. Volkov); 0000-0002-1814-8041 (A. A. Lagutin)

(c) (i) $\odot 2021$ Copyright for this paper by its authors. Use permitted under Creative Commons License Attribution 4.0 International (CC BY 4.0).

$[$ CEUR Workshop Proceedings (CEUR-WS.org) 
The possibility for obtaining regular information on the total methane content in the atmosphere over difficult terrains as well as regions with sparse coverage by ground stations, appeared only in 2002 after the European Space Agency (ESA) had launched the ENVISAT satellite with the SCIAMACHY radiometer on board [4].

The extension of the satellite monitoring of the GHGs was the launch of the GOSAT satellite made by the Japanese Aerospace Agency (JAXA) in January 2009 [5], as well as the OCO-2 satellite observatory launch into a sun-synchronous orbit made by the NASA in July 2014 [6, 7].

A new era in solving the problem of quantitative assessment of emissions of methane, nitrogen dioxide and $\mathrm{CO}$ from both natural and anthropogenic sources began in 2017 after the launch of the Sentinel-5 Precurcor (Sentinel-5P) satellite made by the ESA with the TROPOspheric Monitoring Instrument (TROPOMI) aboard [8, 9]. The main mission of the Sentinel-5P/TROPOMI is to continue monitoring observations of the GHGs content in the Earth's atmosphere, interrupted by the completion of the SCIAMACHY project.

The five imaging systems of the Suomi-NPP satellite [10], launched in October 2011, and the JPSS-1 (NOAA-20) satellite [11], launched in November 2017, also provide unique data for solving the problems of the GHGs monitoring. For example, in [12], data from a 22-channel VIIRS/SNPP/NOAA-20 radiometer [13] were used to estimate the GHGs emissions from the combustion of associated petroleum gas in flares of oil industry enterprises in Western Siberia.

It is clearly that to obtain quantitative estimates of the GHGs emissions, their total content in the atmosphere, to understand the mechanisms of their sinks as well as to obtain long-term forecasts, we need data covering a significant time period with good spatial resolution. These problems can be dealt by means of global and regional climate models as well as chemical transport models along with satellite observations. For example, in $[14,15,16,17,18]$, the success of the application of the Regional Climate Model (RegCM4) for the study of the GHG emissions over Europe, Southeast Asia, India, and northern Africa (Egypt) was shown.

The aim of this work is to simulate the methane emission in the atmosphere of the Siberian region using the chemical version of the regional climate model RegCM-CHEM4.

\section{The regional climate chemistry model: Description and simulation design}

RegCM-CHEM4 is an online climate chemistry model based on the Abdus Salam International Centre for Theoretical Physics (ICTP, Trieste, Italy) regional climate model (RegCM4) [19, 20]. RegCM4 is a hydro- and/or non-hydrostatic, sigma coordinate model, which has been implemented for a wide range of climate researches across the globe. The model includes a wide range of parameterization schemes for physical processes in the atmosphere and underlying surface. In this paper we employ the mass-flux cumulus scheme of Grell [21], the non-local planetary boundary layer parameterization of Holtslag [22], and the Rapid Radiative Transfer Model, RRTM [23]. Surface processes are treated using the Community Land Model version 4.5 [24].

Tropospheric gas-phase chemistry is integrated into the RegCM4 using the fixed sets of schemes which define the nature and number of chemical species and/or transported aerosols. In this study we have chosen the atmospheric chemical transfer scheme CBMZ [25]. This scheme supports over 30 chemical tracers and aerosols. 


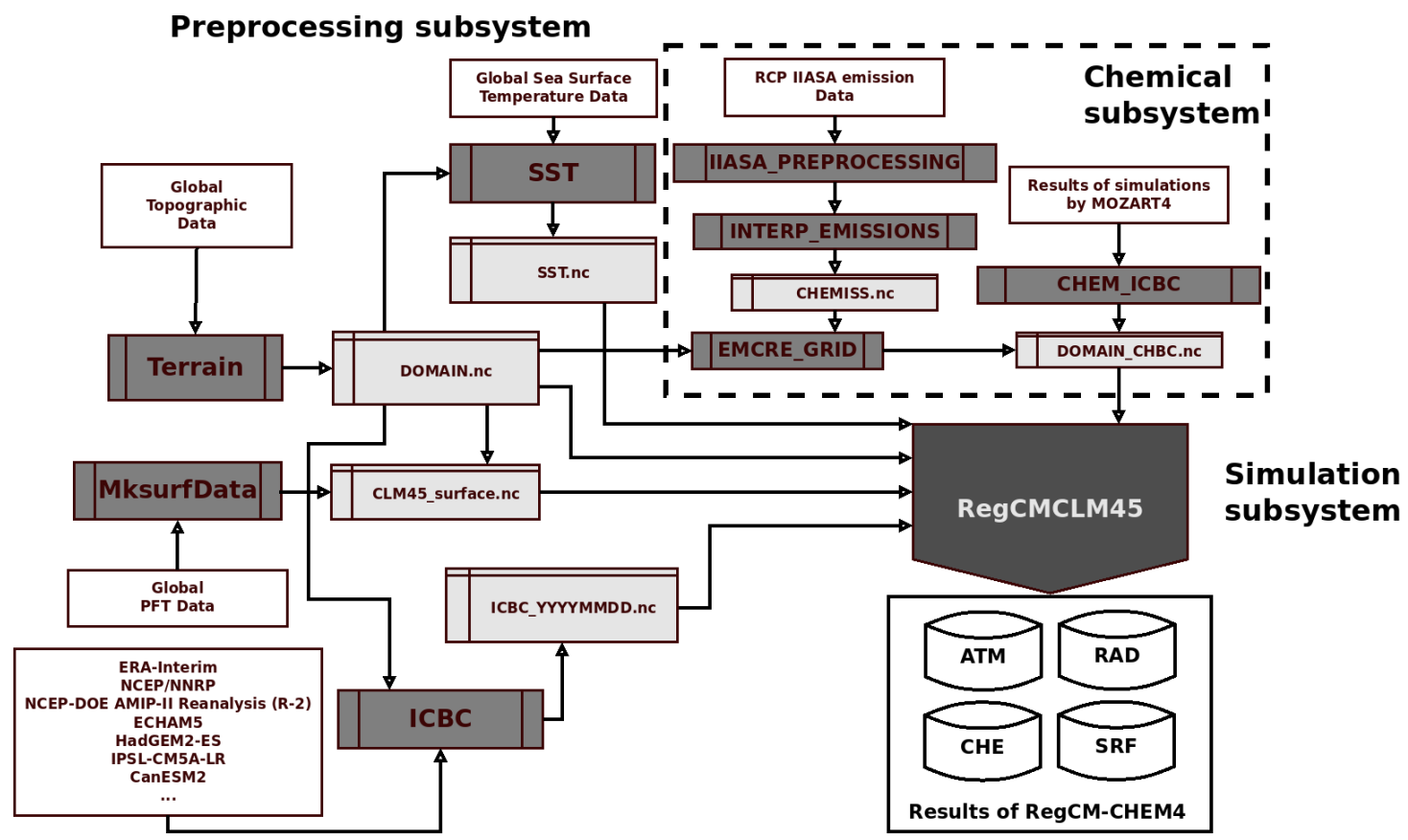

Figure 1: Flowchart for data preparation and simulation using the RegCM-CHEM4.

RegCM4 has a modular structure comprising two main subsystems: preparation of input data and modeling (see $[19,20]$ ). Figure 1 shows a flowchart with the main modules of RegCMCHEM4.

A description of the Terrain, MksurfData, SST and ICBC modules are given in [19, 20]. Configurations of these modules are discussed in series of our previous works [26, 27, 28, 29, 30]. In these works, based on the results of simulations of the contemporary and the future climate of the Siberian region, the verification of the atmospheric and radiation schemes of RegCM4 as well as the Community Land Model, coupled with the RegCM4, were carried out.

The chemical subsystem of the RegCM-CHEM4 is shown in Figure 1 inside the rectangular dashed area. The EMCRE_GRID module is used to create the model grid description file to be used to calculate weights for a remapping. The INTERP_EMISSIONS module is used to interpolation of the global emissions data on the RegCM4 grid. The CHEM_ICBC module is designed to set the boundary conditions of the chemical model.

To test the capability of the coupled RegCM-CHEM4 to simulate atmospheric chemistry of the Siberian region, we perform simulation for 16 years from 1 January 1990 to 31 December 2005. The first five years of the simulation is for climate model spin up and is not included in the analysis time period of 1995-2005. The simulations presented here use a non-hydrostatic dynamical core model with time step of $120 \mathrm{~s}$ with the land model called every $600 \mathrm{~s}$. The main parameters and simulating schemes are shown in Table 1.

The model domain (Figure 2) has a horizontal resolution of $40 \mathrm{~km} \times 40 \mathrm{~km}$ and 18 vertical levels. Because RegCM4 is a limited-area model, meteorological lateral boundary conditions are required. For present-day simulations such as the one here, initial and lateral boundary 
Table 1

Parameters of simulations, configuration of domain and schemes of physical processes employed in this study.

\begin{tabular}{|c|c|c|c|}
\hline \multicolumn{2}{|c|}{ Simulation design } & \multicolumn{2}{|c|}{ Schemes and models } \\
\hline Parameter & Value & Scheme or model & Description \\
\hline Projection & $\begin{array}{l}\text { Lambert conformal } \\
\text { conic projection }\end{array}$ & Surface model & $\begin{array}{l}\text { Community Land } \\
\text { Model, CLM4.5 [24] }\end{array}$ \\
\hline $\begin{array}{l}\text { Central longitude and } \\
\text { latitude }\end{array}$ & $\begin{array}{l}\lambda_{0}=80 \mathrm{E} \\
\phi_{0}=60 \mathrm{~N}\end{array}$ & Radiation scheme & $\begin{array}{l}\text { Rapid Radiative Trans- } \\
\text { fer Model, RRTM [23] }\end{array}$ \\
\hline Standard parallels & $\begin{array}{l}\phi_{1}=52.5 \mathrm{~N} \\
\phi_{2}=67.5 \mathrm{~N}\end{array}$ & $\begin{array}{l}\text { Cumulus convection } \\
\text { scheme }\end{array}$ & Grell [21] \\
\hline $\begin{array}{l}\text { Time step of simula- } \\
\text { tions and the time } \\
\text { intervals in solar } \\
\text { radiation model, chem- } \\
\text { istry solver, cumulus } \\
\text { scheme and land } \\
\text { model. }\end{array}$ & $\begin{array}{l}\Delta t_{\text {atm }}=120 \mathrm{sec}, \\
\Delta t_{\text {rad }}=30 \mathrm{~min} \\
\Delta t_{\text {chem }}=300 \mathrm{sec} \\
\Delta t_{\text {cum }}=5 \mathrm{~min}, \\
\Delta t_{\text {surf }}=10 \mathrm{~min}\end{array}$ & $\begin{array}{ll}\text { Boundary } & \text { layer } \\
\text { scheme } & \end{array}$ & Holtslag PBL [22] \\
\hline $\begin{array}{l}\text { Frequency of writing of } \\
\text { the output fields in the } \\
\text { files }\end{array}$ & $\begin{array}{l}\Delta T_{\text {atm }}=\Delta T_{\text {rad }}= \\
6 \text { hours, } \\
\Delta T_{\text {srf }}=\Delta T_{\text {chem }}= \\
3 \text { hours }\end{array}$ & $\begin{array}{l}\text { Atmospheric chemical } \\
\text { transfer scheme }\end{array}$ & $\begin{array}{ll}\text { Carbon } & \text { Bond } \\
\text { Mechanism-Z, } & \\
\text { CBMZ [25] } & \end{array}$ \\
\hline Lateral buffer zone & 12 cells & $\begin{array}{l}\text { Lateral Boundary con- } \\
\text { ditions scheme }\end{array}$ & $\begin{array}{l}\text { Relaxation, exponen- } \\
\text { tial technique }\end{array}$ \\
\hline
\end{tabular}
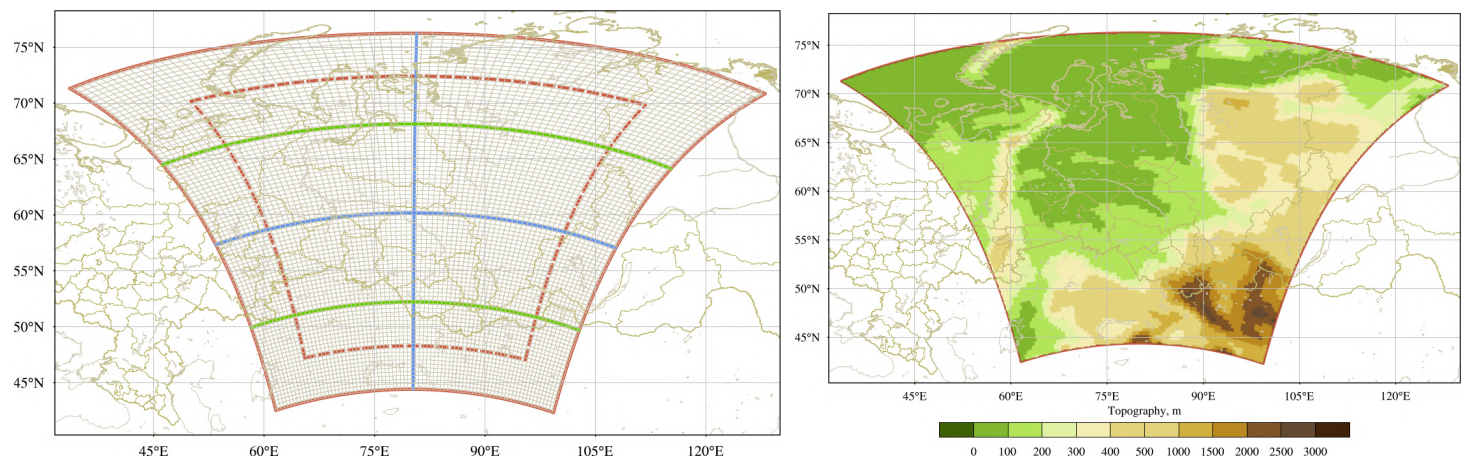

Figure 2: Spatial resolution and projection parameters (left) as well as surface elevation of modeling domain in meters at sea level (right) used in RegCM-CHEM4. Blue lines are the central longitude and latitude of a Lambert conformal conic projection. Green lines are the standard parallels. Dashed lines are the boundaries of relaxation (lateral buffer zone). 
conditions for the meteorological fields are provided by NCEP-DOE AMIP-II Reanalysis (R-2) every six hours [31] with weekly sea surface temperatures (NOAA Optimum Interpolation (OI) SST V2) [32].

To define chemical emissions the global RCP (Representative Concentration Pathways) emission dataset prepared by the International Institute for Applied Systems Analysis (IIASA) was used [33]. For gas phase species, we prepared the 6-hourly chemical boundary conditions from the Model for Ozone and Related chemical Tracers, version 4 (MOZART-4) [34] modified by the authors.

\section{Initial and lateral boundary conditions for chemical subsystem}

The IIASA dataset [33] provides access to global data on the emissions of the following gas components: $\mathrm{CH}_{4}, \mathrm{SO}_{2}, \mathrm{NO}_{x}, \mathrm{CO}, \mathrm{NH}_{3}, \mathrm{BC}$ (Black Carbon), $\mathrm{OC}$ (Organic Carbon), all fluorinated gases controlled under the Kyoto Protocol and ozone depleting substances controlled under the Montreal Protocol. Model data were prepared within the framework of the Coupled Model Intercomparison Project Phase 5 (CMIP5) for the historical period from 1850 to 2005, as well as for the so-called "Representative Concentration Pathway" (RCPs) 2005-2100. The spatial resolution of the data is $0.5^{\circ} \times 0.5^{\circ}$. According to the sectors of emissions, all data are divided into 4 sectors: anthropogenic emissions, as well as emissions from biomass burning, shipping and aviation.

The RegCM-CHEM4 preprocessor can manage IIASA emissions. To implement it, the global $\mathrm{RCP}$ emission dataset have been processed to extract only species adopted in the chemical solver CBMZ. At the next stage, the data sets are aggregated according to different sectors that are presented in the RCP fields.

Figure 3 shows, for example, the spatial distribution of methane sources in the modeling domain for July 2005 according to IIASA RCP emission dataset. It can be seen that the main

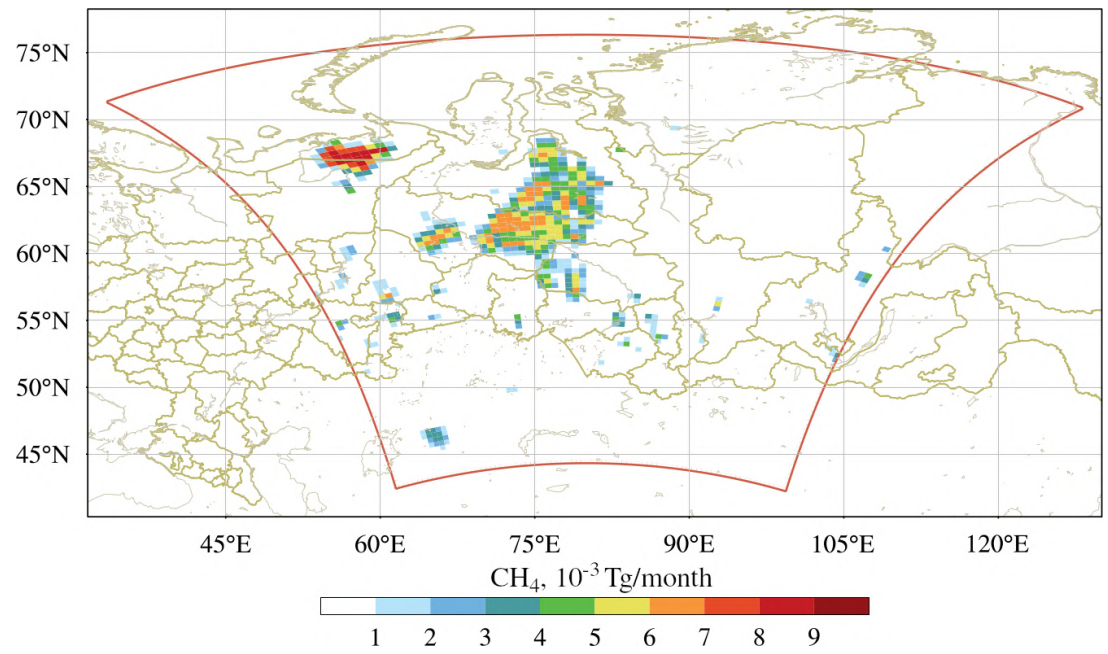

Figure 3: Total monthly emissions (anthropogenic and biomass burning) of $\mathrm{CH}_{4}$ ( $\mathrm{Tg} / \mathrm{month}$ ) for July 2005 according to IIASA RCP emission dataset. 


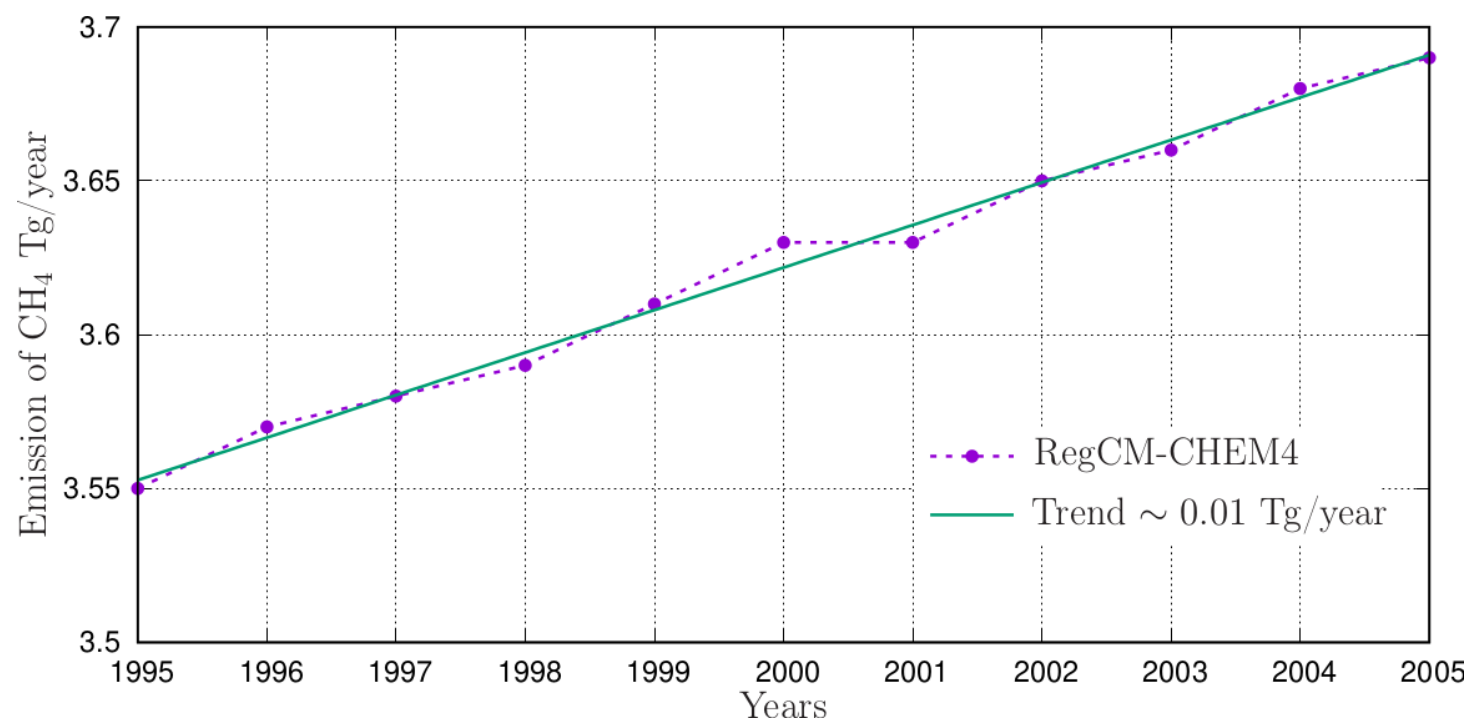

Figure 4: Total annual emissions of $\mathrm{CH}_{4}$ (Tg/yr) in 1995-2005 over Western Siberia's wetland complexes according to RegCM-CHEM4 (purple dots) and the rate of change of methane emission (green line).

sources of methane are located in wetland complexes of Western Siberia as well as large industrial centers of the region.

The original element of this study is the use of the data from the global transport chemical model MOZART-4 modified by authors to set the initial and boundary chemical conditions with an interval of 6 hours (see Egor Yu. Mordvin, Anatoly A. Lagutin, Nikolay V. Volkov "Total methane content in atmosphere of Western Siberia in 2000-2020 according to the data of chemical transport model MOZART-4" in this issue of CEUR Workshop proceedings for details).

\section{Results}

The chemical version of the regional climate model RegCM-CHEM4 was used to simulate methane emissions over the Siberian region in 1995-2005. It should be noted that the subject region contains one of the largest wetland complexes are natural sources of methane. Results of simulations of $\mathrm{CH}_{4}$ emissions in 1995-2005 are shown in Figure 4.

The analysis of the simulation results was carried out only for the zone containing wetland complexes (55-65 N, 65-85 E). It was found that for Western Siberia's wetland complexes the model estimates for methane emission in 1995-2005 changes from $\sim 3.55$ to $\sim 3.69 \mathrm{Tg} / \mathrm{yr}$. The average value of emission is $3.62 \mathrm{Tg} / \mathrm{yr}$, the rate of change of methane emission during this period is $\sim 0.01 \mathrm{Tg} / \mathrm{yr}$.

The quantitative estimates of the methane emission obtained in this paper are in good agreement with the result $3.91 \pm 1.29 \mathrm{Tg} / \mathrm{yr}$ [35], although it slightly exceeds the average estimate of $3.0 \pm 1.4 \mathrm{Tg} / \mathrm{yr}$ obtained in [36] for 2003-2009. 


\section{Acknowledgments}

The study was carried out within the framework of the Program for the support of scientific and pedagogical workers of the Altai State University, the project "Assessment of greenhouse gas emissions by oil industry enterprises in Western Siberia according to satellite observations and modeling".

\section{References}

[1] S. Kirschke, P. Bousquet, P. Ciais et al., Three decades of global methane sources and sinks, Nature Geoscience 6 (2013) 813-823. doi:10 .1038/ngeo1955.

[2] M. Sasakawa, K. Shimoyama, T. Machida et al., Continuous measurements of methane from a tower network over Siberia, Tellus 62B (2010) 403-416. doi:10.1111/j.1600-0889. 2010.00494.x.

[3] M. Y. Arshinov, B. D. Belan, D. K. Davydov, Vertical Distribution of Greenhouse Gases over Western Siberia from Long-term Measurement Data, Atmospheric and Oceanic Optics 22 (2009) 316-324. doi:10 . 1134/S1024856009030087.

[4] H. Bovensmann, J. Burrows, M. Buchwitz et al., SCIAMACHY: Mission Objectives and Measurement Modes, Journal of the Atmospheric Sciences 56 (1999) 127-150. doi:10. 1175/1520-0469(1999) 056<0127: SMOAMM > 2. 0. CO; 2 .

[5] L. Feng, P. Palmer, $\mathrm{H}$. Bosch et al., Consistent regional fluxes of $\mathrm{CH} 4$ and $\mathrm{CO} 2$ inferred from GOSAT proxy XCH4: XCO2 retrievals, 2010-2014, Atmospheric Chemistry and Physics 17 (2017) 4781-4797. doi:10 . 5194/acp-17-4781-2017.

[6] C. Frankenberg, R. Pollock, R. A. M. Lee et al., The Orbiting Carbon Observatory (OCO-2): spectrometer performance evaluation using pre-launch direct sun measurements, Atmospheric Measurement Techniques 8 (2015) 301-313. doi:10 . 5194/amt-8-301-2015.

[7] M. Reuter, M. Buchwitz, O. Schneising et al., Towards monitoring localized CO2 emissions from space: co-located regional $\mathrm{CO} 2$ and $\mathrm{NO} 2$ enhancements observed by the OCO-2 and S5P satellites, Atmospheric Chemistry and Physics 19 (2019) 9371-9383. doi:10.5194/ acp-19-9371-2019.

[8] J. P. Veefkind, I. Aben, K. McMullan et al., TROPOMI on the ESA Sentinel-5 Precursor: A GMES mission for global observations of the atmospheric composition for climate, air quality and ozone layer applications, Remote Sensing of Environment 120 (2012) 70-83. doi:10.1016/j.rse.2011.09.027.

[9] A. Butz, A. Galli, O. Hasekamp et al., TROPOMI aboard Sentinel-5 Precursor: Prospective performance of $\mathrm{CH} 4$ retrievals for aerosol and cirrus loaded atmospheres, Remote Sensing of Environment 120 (2012) 267-276. doi:10.1016/j . rse.2011.05.030.

[10] D. Hillger, T. Kopp, T. Lee et al., First-Light Imagery from Suomi NPP VIIRS, Bulletin of the American Meteorological Society 94 (2013) 1019-1029. doi:10 . 1175/BAMS-D-12- 00097. 1.

[11] S. Uprety, C. Cao, S. Blonski, X. Shao, Evaluating NOAA-20 and S-NPP VIIRS radiometric consistency, Proceedings of SPIE 10781 (2018). doi:10.1117/12.2324464.

[12] A. A. Lagutin, E. Y. Mordvin, N. V. Volkov, N. V. Tuchina, Estimation of Natural Gas Flaring 
Volume at the Western Siberia Flares using Satellite Night-Time Data in the Visible and Near-Infrared Range, CEUR Workshop Proceedings 2534 (2019) 22-26.

[13] C. Cao, F. J. De Luccia, X. Xiong et al., Early On-Orbit Performance of the Visible Infrared Imaging Radiometer Suite Onboard the Suomi National Polar-Orbiting Partnership (SNPP) Satellite, IEEE Transactions on Geoscience and Remote Sensing 52 (2014) 1142-1156. doi:10.1109/TGRS.2013.2247768.

[14] A. Shalaby, A. S. Zakey, A. B. Tawfik et al., Implementation and evaluation of online gas-phase chemistry within a regional climate model (RegCM-CHEM4), Geoscientific Model Development 5 (2012) 741-760. doi:10 .5194/gmd-5-741-2012.

[15] B. Abish, K. Arun, Resolving the weakening of orographic rainfall over India using a regional climate model RegCM 4.5, Atmospheric Research 227 (2019) 125-139. doi:10. 1016/j. atmosres.2019.05.003.

[16] X. Pu, T. J. Wang, X. Huang et al., Enhanced surface ozone during the heat wave of 2013 in Yangtze River Delta region, China, Science of the Total Environment 603-604 (2017) 807-816. doi:10.1016/j.scitotenv.2017.03.056.

[17] A. Saber, H. Abdel Basset, M. Morsy et al., Characteristics of the simulated pollutants and atmospheric conditions over Egypt, NRIAG Journal of Astronomy and Geophysics 9 (2020) 402-419. doi:10.1080/20909977.2020.1755479.

[18] A. N. Mostafa, A. S. Zakey, S. C. Alfaro et al., Validation of RegCM-CHEM4 model by comparison with surface measurements in the Greater Cairo (Egypt) megacity, Environmental Science and Pollution Research 26 (2019) 23524-23541. doi:10.1007/ s11356-019-05370-0.

[19] F. Giorgi, E. Coppola, F. Solmon et al., RegCM4: Model description and preliminary tests over multiple CORDEX domains, Climate Research 52 (2012) 7-29. doi:10 . 3354/cr01018.

[20] J. S. Pal, F. Giorgi, B. Xunqiang et al., Regional climate modeling for the developing world: the ICTP RegCM3 and RegCNET, Bulletin American Meteorological Society 88 (2007) 1395-1409. doi:10.1175/BAMS-88-9-1395.

[21] G. Grell, Prognostic evaluation of assumptions used by cumulus parameterizations, Monthly Weather Review 121 (1993) 764-787. doi:10 .1175/1520-0493(1993) $121<0764$ : $\mathrm{PEOAUB}>2$. 0 . CO; 2 .

[22] A. A. M. Holtslag, E. I. F. de Bruijn, H.-L. Pan, A high resolution air mass transformation model for short-range weather forecasting, Monthly Weather Review 118 (1990) 1561-1575. doi:10.1175/1520-0493(1990)118<1561:AHRAMT>2 . 0 . CO ; 2 .

[23] E. J. Mlawer, S. J. Taubman, P. D. Brown et al., Radiative transfer for inhomogeneous atmospheres: RRTM, a validated correlated-k model for the longwave, Journal of Geophysical Research 102 (1997) 16663-16682. doi:10 . 1029/97JD00237.

[24] D. M. Lawrence, K. W. Oleson, M. G. Flanner et al., Parameterization improvements and functional and structural advances in version 4 of the Community Land Model, Journal of Advances in Modeling Earth Systems 3 (2011) M03001. doi:10 . 1029/2011MS00045.

[25] R. Zaveri, L. K. Peters, A new lumped structure photochemical mechanism for large-scale applications, Journal of Geophysical Research 104 (1999) 30387-30415. doi:10.1029/ 1999JD900876.

[26] A. A. Lagutin, N. V. Volkov, E. Y. Mordvin, A. N. Reznikov, Modelling Western Siberia Climate: Results of the RegCM4 Model, Bulletin of Altai State University (2012) 181-189 
(in Russian).

[27] A. A. Lagutin, N. V. Volkov, E. Y. Mordvin, Modelling Siberian Region Climate: Results of the RegCM/CLM Model for 1970-2029, Vestnik Altaiskoy Nauki (2013) 191-197 (in Russian).

[28] A. A. Lagutin, N. V. Volkov, K. Makushev, E. Y. Mordvin, Outgoing Longwave Radiation from the Data of Regional Climate Model and AIRS/AMSU Satellite Suite, Bulletin of Altai State University (2014) 155-161 (in Russian).

[29] K. M. Makushev, A. A. Lagutin, N. V. Volkov, E. Y. Mordvin, Validation of the RegCM4/CLM4.5 regional climate modeling system over the Western Siberia, Proceedings of SPIE 10035 (2016). doi:10 . 1117/12.2249163.

[30] A. A. Lagutin, N. V. Volkov, E. Y. Mordvin, The Influence of a Global Climate Changes on Western Siberia Climate in the First Half of XXI Century, Computational Technologies 23 (2018) 83-94 (in Russian). doi:10 . 25743/ICT . 2018.23.16505.

[31] M. Kanamitsu, W. Ebisuzaki, J. Woollen, NCEP-DOE AMIP-II REANALYSIS (R-2), Bulletin of the American Meteorological Society 83 (2002) 1631-1643. doi:10.1175/ BAMS - 83-11- 1631.

[32] NOAA-ESRL Physical Sciences Laboratory, Boulder Colorado, Last access: July 25, 2021. URL: https://psl.noaa.gov/.

[33] Technical specification. RCP Database Version 2.0.5, Last access: July 25, 2021. URL: https://tntcat.iiasa.ac.at/RcpDb.

[34] L. K. Emmons, S. Walters, P. G. Hess et al., Description and evaluation of the Model for Ozone and Related chemical Tracers, version 4 (MOZART-4), Geoscientific Model Development 3 (2002) 43-67. doi:10 . 5194/gmd-3-43-2010.

[35] M. Glagolev, I. Kleptsova, I. Fillipov et al., Regional methane emission from West Siberia mire landscapes, Environmental Research Letters 6 (2011) 045214. doi:10 . 1088 / 1748-9326/6/4/045214.

[36] H. S. Kim, S. Maksyutov, M. V. Glagolev et al., Evaluation of methane emissions from West Siberian wetlands based on inverse modeling, Environmental Research Letters 6 (2011) 035201. doi:10 . 1088/1748-9326/6/3/035201. 